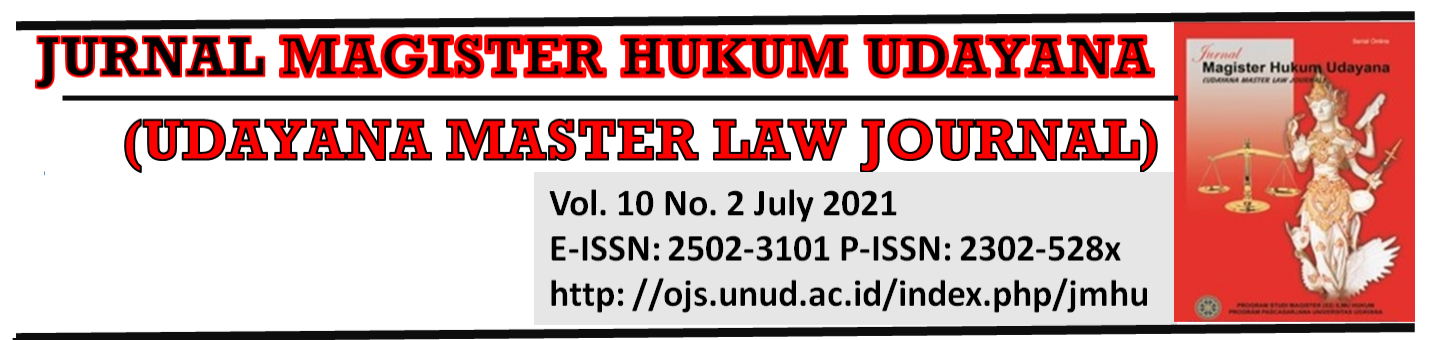

\title{
The Role of Family in Fulfilling the Right to Education During the Covid-19 Pandemic: A Socio- Legal Approach
}

\author{
Anak Agung Istri Ari Atu Dewi ${ }^{1}$, Putri Triari Dwijayanthi ${ }^{2}$, \\ Cokorde Istri Dian Laksmi Dewi ${ }^{3}$
}

1Faculty of Law, Udayana University, E-mail: ari_atudewi@unud.ac.id

2RAH the House of Legal Experts, E-mail: putritriari@rahlegalexperts.com

3Faculty of Law, Ngurah Rai University, E-mail: cokdild@gmail.com

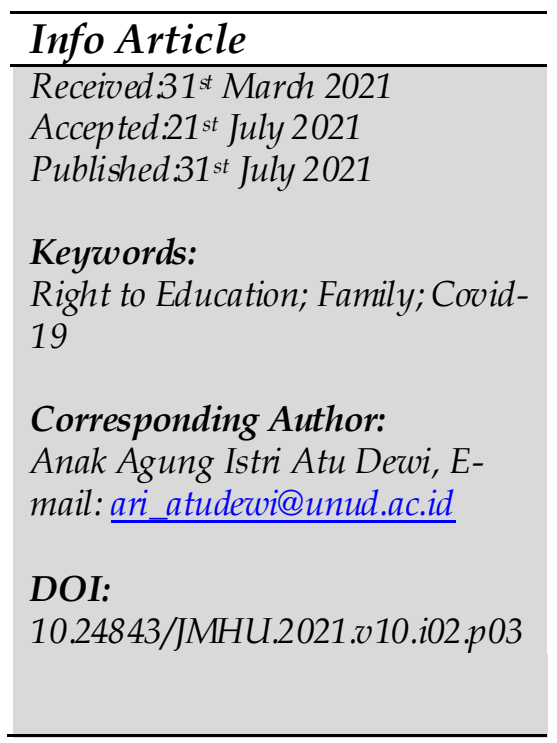

Abstract
This paper aims to identify, analyze and elaborate on the role of
the family in fulfilling the right to education during the Covid-19
pandemic as well as a model for family participation in fulfilling
the right to education during the Covid-19 pandemic. This is a
socio-legal researdh method or socio-legal research which
examines the text and context with a statutory approadh
combined with the conditions in the community. The results
show that online school is the best solution to guarantee the right
to education as stipulated in Surat Edaran Nomor 15 of 2020
concerning Guidelines for Organizing Learning from Home in
an Emergency for the Spread of Covid-19 and family role models
in an effort to fulfill the right to education during the Covid-19
pandemic, which is in the form of awareness from parents or
guardians to provide assistance during learning from home
activities.

\section{Introduction}

Since 2019, the entire world has been hit by the Covid-19 Pandemic, including Indonesia. This pandemic condition caused development and movement in all sectors to be hampered and even stalled. Covid-19 is caused by a corona virus, which attacks the respiratory system. This virus causes mild to acute respiratory infections. In some cases, most infected people will experience flu-like symptoms accompanied by loss of smell. At first, some scientists assumed that this virus was transmitted from animals to humans, but then it was also transmitted from human to human in its development. The mode of transmission occurs through saliva or droplets because the person is holding the mouth or nose without washing hands or using a hand-sanitizer. In addition, close contact with sufferers of Covid-19 can increase the rate of transmission of this virus.

This condition was declared a pandemic by World Health Organization (hereinafter WHO) and also declared a national non-natural disaster by the Government of the Republic of Indonesia. This is determined by Presidential Decree No.11 of 2020 concerning the Determination of the Corona Virus Disease 2019 (COVID-19) Public Health Emergency. 
The Covid-19 pandemic has also brought significant changes in the education sector in all over the world, including in Indonesia. Massive changes occur simultaneously, which demands that the learning process be carried out online and carried out from home in order to prevent the spread to children at school. Parents also worry about the possibility of spreading the virus in the school environment.

There are 2 (two) impacts for the fulfillment of education resulting from the COVID-19 pandemic. In the short term, the impact of the pandemic is strongly felt by Indonesians. Many impacts resulted from the existence of COVID 19, one of which is the implementation of education in Indonesia. During the Covid-19 pandemic, the State is obliged to take action by issuing a policy to learn from home as a form of fulfillment of the right to education for the community. The learning process at school is done at home supported by internet facilities to be able to interact through online.

In this context, at first many people are not ready to do the learning process activities done at home. Most people are unfamiliar with the change. This is a challenge for parents and families who are used to being busy with work outside the home, however they have to accompany their children to participate in learning activities from home during the pandemic. Psychological problems are also experienced by children who are used to formal learning in school.

The implementation of the policy concerning school from home has caused confusion to all the stakeholders especially with regard to the limited information technology infrastructure and the capabilities and skills of the teachers are also limited in the use of technology. In this context the fulfillment of the right to education becomes constrained. The policy of learning process conducted online from home causes the role of outbound to be increased, especially in the participation of families in the success of the learning process from home. In the current pandemic conditions, there appears to be a gap between law in book and law in action. Referring to some provisions of the legislation it appears that the right to education is part of the human rights guaranteed by the state, unfortunately in the current pandemic, the fulfillment of the right to education is experiencing some obstacles that require participation from various parties includ ing the family to facilitate the needs of children in relation to the fulfillment of the right to education.

According to the explanation abovementioned, it is important to examine and analyze in-depth with regard to issue about the role of family in fulfilling the right to education during the Covid-19 pandemic as well as the participation of the family in the fulfillment of the right to education and the model of family participation in accommodating the fulfillment of right to education during the Covid-19 pandemic.

Compared to previous study, this research has similarities in terms of topics, namely both examine the right to education, but the focus of the study is different. This study emphasized on the regulation of the role of family in fulfilling the right to education during the Covid-19 pandemic as well as the model of family participation in the fulfillment of the right to education during the Covid-19 pandemic. 
Previous study conducted by Hwian Chistianto in 2020, which examine ${ }^{12}$ This writing examines the importance of the right to education during the Covid-19 pandemic as well as the relationship between the right to information and the use of internet. This writing also examines violations related to the right to education and their relationship to criminal law. ${ }^{34}$ This writing examines the education in the family as a superior strategy to maintain children's rights, namely education.

The writing aims to identify, analyze and elaborate family role arrangements and family participation models in fulfilling the right to education during the Covid-19 pandemic. To achieve the purpose of writing, this paper will discuss the relevant substance with the focus of the problem systematically. First, it is presented about regulating the role of the family in fulfilling the right to education during the Covid-19 pandemic. Second, the model of family participation in fulfilling the right to education during the Covid-19 pandemic.

\section{Research Method}

This is a socio-legal reasearch that examines both text and context. In this case, the study of the text is in the form of legal text that is in the form of the text of legislation combined with the study of the context that is to see the work of the law in the community. Related to this, Sulistyowati Irianto emphasized that sociosolegal research uses a combination of doctrinal and nondoctrinal research (empirical). ${ }^{5}$ Soetandyo Wignjosoebroto also stated that research that uses a concurrent approach between doctrinal and non-doctrinal support is mutually supportive in a legal study.

The technique of collecting legal materials is done by collecting, inventorying legal materials and recording in detail related to the subject matter discussed. The technicality of the analysis of primary and secondary legal materials uses legal hermeneutics, namely an interpretation of the legal text associated with context (seeking meaning to the legal text and seeking ideas behind the legal text).

\section{Result and Discussion}

\subsection{Regulation concerning the Role of Family in the Fulfillment of the Right to Education during the Covid-19 Pandemic}

Education is the initial capital in human life. It is used to develop and increase selfpotential in accordance with the culture. ${ }^{6}$ Refers to the provisions in Article 1 number 1

\footnotetext{
${ }^{1}$ Hwian Christianto, "Penggunaan Media Internet Dalam Pemenuhan Hak Atas Pendidikan Di Masa Pandemi Covid-19: Perspektif Hak Asasi Manusia Dan Hukum Pidana," Jurnal HAM 11, no. 2 (2020): 239-53, https://doi.org/http://dx.doi.org/10.30641/ham2020.11 239-253.

2 Ibid.

${ }^{3}$ Renti Oktaria and Purwanto Putra, "Pendidikan Anak Dalam Keluarga Sebagai Strategi Pendidikan Anak Usia Dini Saat Pandemi COVID-19," Jurnal Ilmiah Pesona PAUD 7, no. 1 (2020): 41-51, https://doi.org/https://doi.org/10.24036/108806.

4 Ibid.

${ }^{5}$ Sulistyowati Irianto, Metode Penelitian Hukum Konstelaasi Dan Refleksi (Jakarta: Yayasan Obor Indonesia, 2009).

${ }^{6}$ Lukman Hakim, "Pemerataan Akses Pendidikan Bagi Rakyat Sesuai Dengan Amanat UndangUndang Nomor 20 Tahun 2003 Tentang Sistem Pendidikan Nasional," EduTedh: Jurnal Ilmu
} 
of Law Number 20 of 2003 concerning the National Education System (hereinafter Sisdiknas Law) 7 , which stipulated that:

"Education is a conscious and planned effort to realize the atmosphere of learning and learning process so that learners actively develop their potential to have religious spiritual power, self-control, personality, intelligence, noble morals and skills required of themselves, society, nation and country".

Education is seen as a fundamental and inseparable right from human life as a citizen. The right to education is also seen as one of the most important human rights to be fulfilled as well as the fulfillment of the right to work, freedom of speech and information, the right to participate in political, economic, social and cultural activities. ${ }^{8}$

The regulation on the right to education as a constitutional right is stipulated in the provisions of Article 28C paragraph (1) of the Constitution of the Republic of Indonesia of 1945 (hereinafter the 1945 Indonesia Constitution) ${ }^{9}$ which mainly provides the right to education that is by ensuring the benefits derived from science and technology, arts and culture, in an effort to improve the quality of life and to achieve well-being for mankind.

The guarantee of the right to education in Indonesia is also stipulated in the provisions of Article 31 paragraph (1) of the 1945 Indonesia Constitution which clearly provides the right for every Indonesian citizen to get an education. This right guarantee is also provided by the obligation of the government to finance the cost of education for each citizen as specified in the provisions of Article 31 paragraph (2) of the 1945 Indonesia Constitution which essentially obliges every citizen to obtain education and be financed by the state.

The government also strives to fulfill these rights by establishing the allocation of education funds. ${ }^{10}$ It is stated in the provisions of Article 31 paragraph (4) of the 1945 Indonesia Constitution, which determines the priority size of the education budget at least $20 \%$ (twenty percent) of the state budget including from the regional budget of revenue and expenditure used for the fulfillment of the needs in the implementation of national education for citizens. The regulation of the right to education in the 1945 Indonesia Constitution shows that the right to ed ucation is recognized as the content of

\footnotetext{
$\begin{array}{lllllll}\text { Pendidikan Dan Ilmu } & \text { Sosial } & 2, & \text { no. } & 1 & \text { (2016), }\end{array}$ https://doi.org/http://dx.doi.org/10.30596\%2Fedutech.v2i1.575.

7 “Undang-Undang Nomor 20 Tahun 2003 Tentang Sistem Pendidikan Nasional, Lembaran Negara Republik Indonesia Tahun 2003 Nomor 78, Tambahan Lembaran Negara Republik Indonesia Nomor 4301" (2003).

${ }^{8}$ Manfred Nowak, "Right to Education," in Human Rights or Global Capitalism (University of Pennsylvania Press, 2016), 57-66.

9 “Undang Undang Dasar Negara Republik Indonesia Tahun 1945," 4 § (2019), https://doi.org/10.31227/osf.io/498dh.

${ }^{10}$ E. Sujatmoko, "Hak Warga Negara Dalam Memperoleh Pendidikan," Jurnal Konstitusi 7, no. 1 (2010): 181-212, https:// doi.org/https:// doi.org/10.31078/jk\%25x.
} 
the constitution that binds the central government and local government, even the responsibility of everyone and citizens. ${ }^{11}$

It is also regulated in Law No. 39 of 1999 on Human Rights (hereinafter Human Right Law) ${ }^{12}$, which also emphasizes the importance of fulfilling the right to education as set forth in the provisions of Article 12, namely:

"Everyone has the right to protection of his self-development, to obtain an education, to educate himself, and to improve the quality of his life to become responsible, content, and prosperous people, in accordance with his human rights.".

Similar provisions are also stipulated in Article 60 of the Human Rights Law, which essentially governs the rights held by each child to obtain education and teaching in accordance with the ability and level of intelligence possessed by the child .

Recognition of rights to education is also regulated internationally through the International Agreement on Economic, Social and Cultural Right (hereinafter ICESCR) which is based on the provisions in Article 13 and Article 14 that specifically govern on the right to education. ${ }^{13}$ The provision of Article 13-point (1) ICESCR stipulated that:

"The States Parties to the presesent Covenant recognize the right of everyone to education. They agree that education shall be directed to the full development of the human personality and the sense of its dignity, and shall strengthen the respect for human rights and fundamental freedoms. They further agree that education shall enable all persons to participate effectively in a free society, promote understanding, tolerance and friendship among all nations and all racial, ethnic or religious groups, and further the activities of the United Nations for the maintenance of peace".

In order to fulfill the right to education, the role of the family is very strategic to realize the national educational goals. The strategic role can be done by synergy of education implementation between educators, families and the community. The efforts to support the strengthening of character education, Regulation of the Minister of Education and Culture No. 30 of 2017 especially in Article 7, which essentially regulates the form of family participation in the form of efforts to foster the values of children's character in the family environment, provide motivation to children for the spirit of learning, encourage literacy culture and facilitate the needs of children to learn.

During the Covid-19 pandemic resulted in drastic changes in education. The character of this virus that can spread very quickly demands the government to take swift and appropriate action. Various policies were issued by the government to address and prevent the spread of this virus, such as the enforcement of social distancing, physical

${ }^{11}$ Hernadi Affandi, "Tanggung Jawab Negara Dalam Pemenuhan Hak Atas Pendidikan Menurut Undang-Undang Dasar Tahun1945," Jurnal Hukum Positum 1, no. 2 (2017): 218, https://doi.org/10.35706/ positum.v1i2.848.

12 “Undang-Undang No. 39 Tahun 1999 Tentang Hak Asasi Manusia, Lembaran Negara Republik Indonesia Tahun 1999 Nomor 165, Tambahan Lembaran Negara Republik Indonesia Nomor 3886," Undang-Undang Republik Indonesia Nomor 39 Tahun 1999 tentang Hak Asasi Manusia § (1999).

${ }^{13}$ The United Nations, "International Covenant on Economic, Social and Cultural Rights," Synergies in Minority Protection: European and International Law Perspectives $§(2009)$, https://doi.org/10.1017/CBO9780511575372.009. 
distancing, even the implementation of Large-Scale Social Restrictions (hereinafter PSBB) in some areas. ${ }^{14}$

The education sector has been taken seriously by the government due to the Covid-19 pandemic. To prevent the spread of this virus, the government took a step that has almost never been done before, namely distance-learning or also known as online school.15 This condition requires all stakeholders to adapt to the online learning system that is expected to develop teaching and learning skills in the $21^{\text {st }}$ century including critical thinking patterns, creativity, collaboration and communication accompanied by the ability to use and access science resources online..$^{16}$

Distance-learning system that is now a solution to continue to fulfill the right to education for all citizens is done by utilizing various digital platforms, such as Whatsapp and Zoom. ${ }^{17}$ To support the government's efforts in carrying out these activities, there needs to be cooperation from all stakeholders, namely educators, students and even parents.

In the implementation of distance-learning, the role of parents at home to accompany children during the learning process is increasingly tested. ${ }^{18}$ The condition of parents who are also actively working becomes one of the challenges in the efforts to fulfill the right to education for children. Under normal conditions, education is conducted through educational institutions such as schools, hence parents can work properly. ${ }^{19}$ Nowadays, the role of educators should be in accordance with the role of parents as an extension of the hands of the educators. Educators not only provide tasks through digital platforms, but also provide support and direction to parents in carrying out the role of teacher at home. ${ }^{20}$

Parents have an important role as the first and foremost educator in the developmental process of a child. ${ }^{21}$ The condition of online school provides opportunities for parents to support the children's learning process. ${ }^{22}$ To prevent boredom of children in learning, parents need to show their support by creating a comfortable learning atmosphere for the child. ${ }^{23}$ Parents can use various media to help their child in the

${ }^{14}$ Luh Devi Herliandry et al., "Pembelajaran Pada Masa Pandemi Covid-19," JTP - Jurnal Teknologi Pendidikan 22, no. 1 (2020): 65-70, https://doi.org/1021009/jtp.v22i1.15286.

15 Ibid.

${ }^{16}$ A Priyadarshini and R Bhaumik, "E-Readiness of Senior School Leamers to Online Learning Transition amid COVID-19 Lockdown," Asian Journal of Distance Education 15, no. 1 (2020): $244-56$.

${ }^{17}$ Jaka Wijaya Kusuma and Hamidah Hamidah, "Perbandingan Hasil Belajar Matematika Dengan Penggunaan Platform Whatsapp Group Dan Webinar Zoom Dalam Pembelajaran Jarak Jauh Pada Masa Pandemik Covid 19," JIPMat 5, no. 1 (2020), https://doi.org/10.26877/jipmat.v5i1.5942.

${ }_{18}$ Oktaria and Putra, "Pendidikan Anak Dalam Keluarga Sebagai Strategi Pendidikan Anak Usia Dini Saat Pandemi COVID-19."

19 Ibid.

${ }^{20}$ Ibid.

${ }^{21}$ Wahyu Trisnawati and Sugito Sugito, "Pendidikan Anak Dalam Keluarga Era Covid-19," Jurnal Obsesi: Jurnal Pendidikan Anak Usia Dini 5, no. 1 (2020): 823-31, https://doi.org/10.31004/obsesi.v5i1.710.

22 Ibid.

${ }^{23}$ Herliandry et al., "Pembelajaran Pada Masa Pandemi Covid-19." 
learning process, such as television, videos on youtube or even some experiments in knowledge books. ${ }^{24}$

The Government through the Ministry of Education and Culture (hereinafter Kemendikbud) issued a Circular Letter Number 15 of 2020 concerning the Guidelines for Learning from Home in the Emergency Period of The Spread of Covid-19.25 Based on the circular, it can be understood that the safety and mental health of all stakeholders is the main consideration in the implementation of Learning from Home activities (hereinafter Learn from home). This activity prioritizes a pattern of good interaction and communication between teachers, students and parents/guardians.

The similar idea is also governed by the Government of Bali Province as an effort to prevent and counter coronavirus. The Government of Bali Province through Circular Letter Number 51/Satgas Covid19/II/2020 concerning the Implementation of Education Policy In The Emergency Period of Corona Virus Disease (COVID-19) Spread in Bali Province. According to the circular, the Bali Provincial Government emphasized that home learning activities are conducted through online learning as an effort to provide a meaningful learning experience for students and can be focused on life skills education, without being burdened with the demands of completing all curriculum achievements for class as well as graduation.

Based on the abovementioned, it can be understood that due to the Covid-19 pandemic, the government continues to strive for the fulfillment of the right to education for each of its citizens. Distance education is the best solution that can be done by all stakeholders to ensure the right to education remains fulfilled as well as an effort to maintain the safety and mental health of all parties involved in distance education activities. The success of distance education can not be separated from the pattern of interaction and communication between teachers, students and parents/guardians. Parents as the main educator for a child, is now required to be an extension of the hand of the teacher in the school to provide and accompany the child in the teaching and learning process that is usually done in school. Parents' creativity is now increasingly tested as an effort to convey lesson materials and provide a comfortable environment for children to be able to stimulate the child's ability to learn by utilizing various communication media to access various tasks and directions from teachers during the distance learning process.

\subsection{Model of the Role of Family in the Fulfillment of the Right to Education during the Covid-19 Pandemic}

Families, especially parents, are the primary educators for a child. In an effort to fulfill the right to education, there is an optimal role of the family to cooperate with the government and educators to actively participate in accompanying, assisting and facilitating the needs of children in learning from home conducted during the Covid-19 pandemic.

The role model of the family that can be applied is the active role of the parent or guardian of the child whose arrangements are explicitly regulated in local policies as well as arrangements in indigenous law in accordance with the local wisdom that is

24 Ibid.

25 “Kementerian Pendidikan Dan Kebudayaan » Republik Indonesia," n.d. 
lived and trusted by the local community. One of the family role models that can be applied in fulfillment of the right to education during the Covid-19 pandemic is the presence of parents to accompany, accompany and educate the child when making tasks.

During the Covid-19 pandemic, the role of the family to support and fulfill children's educational rights can be done in a way 1) create family harmony to support the smoothness and comfort of the teaching and learning process from home, 2) The agreement between parents and children on techniques in learning from home, 3) Parental attention to children during home learning, 4) critical communication in the family environment, 5) parents give appreciation to the child about the learning outcomes so as to increase the spirit of the child in learning from home, 6) parents continue to monitor the learning process of the child while at home with the aim of improving the child's achievements.

The family role model can be socialized by the government both at the central level, at the regional level even at the village level by utilizing the involvement of indigenous villages in the fulfillment of the right to education. As an effort to fulfill the right for citizens to education, the village there can make a pararem or customary village decision that regulates the pattern of learning activities from home by involving the family, namely the parents or guardians of the child itself.

In addition, the indigenous village can also help facilitate the provision of gadgets and internet facilities as an effort to fulfill the right to education by utilizing facilities owned by the village, such as providing free internet in the village hall while implementing health protocols that can be utilized by children to participate in learning activities from home. The indigenous village can also make regulations regarding the role of parents in supervising children who use internet facilities provided in the village hall. Assistance distributed by indigenous villages such as this can be utilized by various parties, so that learning activities from home is not a major obstacle in the fulfillment of the right to education.

Harmonious and reciprocal relationship between law and society ideally needs to be realized in order to fulfill the right to education during the current Covid-18 pandemic. To create a harmonious and reciprocal relationship between law and society, the legal structure, legal substance and legal culture must be interconnected with each other. This is in accordance with the theory of the legal system from Lawrence M. Friedman, which states that the law consists of 3 (three) components, namely the legal structure, legal substance and legal culture. ${ }^{26}$ This theory essentially emphasizes the relationship between legislation as a national law and the law that lives in the community (the living law) to achieve the purpose or mind of the law itself.

Based on the explanation abovementioned, it can be understood that, family or parents are the main educators for children. The role model of the family in the effort to fulfill the right to education during the Covid-19 pandemic is in the form of awareness from parents or guardians to provide assistance during home learning activities conducted by children. Assistance also needs to be supported by the fulfillment and provision of gadgets and internet facilities. In this case, the indigenous village can work with the

${ }^{26} \mathrm{Ni}$ Nyoman Sukerti and I Gst Ayu Agung Ariani, "Budaya Hukum Masyarakat Adat Bali Terhadap Eksistensi Perkawinan Beda Wangsa," Jurnal Magister Hukum Udayana (Udayana Master Law Journal) 7, no. 4 (2018): 516-28, https://doi.org/1024843/jmhu.2018.v07.i04.p07. 
family to provide facilities in the form of gadgets and internet services by utilizing the facilities owned by the indigenous village. With the cooperation and awareness from the family and indigenous village parties, it is hoped that learning from home or distance learning will not be an obstacle to the fulfillment of the right to education.

\section{Conclusion}

Based on the explanation abovementioned, it can be concluded that the arrangement regarding the role of the family in efforts to fulfill the right to education for children during the Covid-19 pandemic has been stipulated in legislation and some government policies. In principle, in the event of the Covid-19 pandemic, the government continues to strive for the fulfillment of the right to education for each of its citizens as stipulated in article 28C paragraph (1) of 1945 Indonesia Constitution. Distance-education is the best solution that can be done by all stakeholders to ensure the right to education remains fulfilled as well as an effort to maintain the safety and mental health of all parties involved. This is further affirmed by the issuance of Circular Letter No. 15 of 2020 concerning Guidelines for The Implementation of Learning from Home in the Emergency Period of the Spread of Covid-19. The success rate is also inseparable from the pattern of interaction and communication between educators, namely teachers, students and parents/guardians. The role model of the family in the effort to fulfill the right to education during the Covid-19 pandemic is in the form of active participation supported by the awareness of parents or guardians to provide assistance during learning activities from home carried out by children. Assistance also needs to be supported by the fulfillment and provision of gadgets and internet facilities. In this case, the village can work with the family to provide facilities in the form of gadgets and internet services by utilizing the facilities owned by the traditional village. Hence, distance-learning will not be an obstacle to the fulfillment of the right to education.

\section{References}

Affandi, Hernadi. "Tanggung Jawab Negara Dalam Pemenuhan Hak Atas Pendidikan Menurut Undang-Undang Dasar Tahun1945." Jurnal Hukum Positum 1, no. 2 (2017): 218. https://doi.org/10.35706/positum.v1i2.848.

Christianto, Hwian. "Penggunaan Media Internet Dalam Pemenuhan Hak Atas Pendidikan Di Masa Pandemi Covid-19: Perspektif Hak Asasi Manusia Dan Hukum Pidana." Jurnal HAM 11, no. 2 (2020): 239-53. https://doi.org/http://dx.doi.org/10.30641/ham.2020.11.239-253.

Hakim, Lukman. "Pemerataan Akses Pendidikan Bagi Rakyat Sesuai Dengan Amanat Undang-Undang Nomor 20 Tahun 2003 Tentang Sistem Pendidikan Nasional." EduTech: Jumal Ilmu Pendidikan Dan Ilmu Sosial 2, no. 1 (2016). https://doi.org/http://dx.doi.org/10.30596\%2Fedutech.v2i1.575.

Herliandry, Luh Devi, Nurhasanah Nurhasanah, Maria Enjelina Suban, and Heru Kuswanto. "Pembelajaran Pada Masa Pandemi Covid-19." JTP - Jurnal Teknologi Pendidikan 22, no. 1 (2020): 65-70. https://doi.org/10.21009/jtp.v22i1.15286.

Irianto, Sulistyowati. Metode Penelitian Hukum Konstelaasi Dan Refleksi. Jakarta: Yayasan Obor Indonesia, 2009.

“Kementerian Pendidikan Dan Kebudayaan » Republik Indonesia," n.d.

Kusuma, Jaka Wijaya, and Hamidah Hamidah. "Perbandingan Hasil Belajar 
Matematika Dengan Penggunaan Platform Whatsapp Group Dan Webinar Zoom Dalam Pembelajaran Jarak Jauh Pada Masa Pandemik Covid 19." JIPMat 5, no. 1 (2020). https://doi.org/10.26877/jipmat.v5i1.5942.

Nowak, Manfred. “Right to Education." In Human Rights or Global Capitalism, 57-66. University of Pennsylvania Press, 2016.

Oktaria, Renti, and Purwanto Putra. "Pendidikan Anak Dalam Keluarga Sebagai Strategi Pendidikan Anak Usia Dini Saat Pandemi COVID-19." Jurnal Ilmiah Pesona PAUD 7, no. 1 (2020): https://doi.org/https://doi.org/10.24036/108806.

Priyadarshini, A, and R Bhaumik. "E-Readiness of Senior School Learners to Online Learning Transition amid COVID-19 Lockdown." Asian Joumal of Distance Education 15, no. 1 (2020): 244-56.

Sujatmoko, E. "Hak Warga Negara Dalam Memperoleh Pendidikan." Jurnal Konstitusi 7, no. 1 (2010): 181-212. https://doi.org/https://doi.org/10.31078/jk\% 25x.

Sukerti, Ni Nyoman, and I Gst Ayu Agung Ariani. "Budaya Hukum Masyarakat Adat Bali Terhadap Eksistensi Perkawinan Beda Wangsa." Jurnal Magister Hukum Udayana (Udayana Master Law Journal) 7, no. 4 (2018): 516-28. https://doi.org/10.24843/jmhu.2018.v07.i04.p07.

The United Nations. International Covenant on Economic, Social and Cultural rights, Synergies in Minority Protection: European and International Law Perspectives § (2009). https://doi.org/10.1017/CBO9780511575372.009.

Trisnawati, Wahyu, and Sugito Sugito. "Pendidikan Anak Dalam Keluarga Era Covid19." Jurnal Obsesi : Jurnal Pendidikan Anak Usia Dini 5, no. 1 (2020): 823-31. https://doi.org/10.31004/obsesi.v5i1.710.

Undang-Undang No. 39 Tahun 1999 Tentang Hak Asasi Manusia, Lembaran Negara Republik Indonesia Tahun 1999 Nomor 165, Tambahan Lembaran Negara Republik Ind onesia Nomor 3886, Undang-Undang Republik Indonesia Nomor 39 Tahun 1999 tentang Hak Asasi Manusia § (1999).

Undang-Undang Nomor 20 Tahun 2003 tentang Sistem Pendidikan Nasional, Lembaran Negara Republik Indonesia Tahun 2003 Nomor 78, Tambahan Lembaran Negara Republik Indonesia Nomor 4301 (2003).

Undang Undang Dasar Negara Republik Indonesia Tahun 1945, 4 § (2019). https://doi.org/10.31227/osf.io/498dh. 